\title{
Yellow-banded Mangrove Snakes (Cantoria violacea) Consume Hard-shelled Orange Signaler Crabs (Metaplax elegans)
}

\author{
Sameer Ghodke ${ }^{1}$, Manish Chandi ${ }^{1}$, and Vardhan Patankar ${ }^{2}$ \\ ${ }^{1}$ ANET (Andaman Nicobar Environment Team), North Wandoor South Andaman island, Andaman and Nicobar Islands, India \\ (sameerghodke73@gmail.com; manish.chandi@gmail.com) \\ ${ }^{2}$ National Center for Biological Sciences (NCBS), Bangaluru, Karnataka, India (vardhanpatankar@gmail.com)
}

Photographs by the senior author.

$\mathrm{D}$ ata on the diet of Yellow-banded Mangrove Snakes (Cantoria violacea) are sparse and contradictory. Earlier studies (Boulenger 1890; Smith 1943; Gyi 1970) failed to document the diet. Frith and Boswall (1978) stated that a snake was found on a mud flat with its head down a crab burrow on Phuket Island. Mattison (1995) said that these snakes feed mainly on fish. Das (2002) reported that C. violacea presumably feeds on fish. Voris and Murphy (2002) reported that it feeds exclusively on Alpheus shrimp. Whitaker and Captain (2004) reported that these snakes feed on small fish and shrimp, and suggested that they might also eat small crabs. Murphy (2007) examined gut content of four specimens; one contained a complete female Giant Snapping Prawn (Alpheus microrhynchus), the others partially digested remains of the same prey.

During a June 2017 survey of homalopsid snakes in the Nakabwe mudflat (Fig. 1), Middle Andaman Islands, India, we observed four Yellow-banded Mangrove Snakes feeding on hard-shelled Orange Signaler Crabs (Metaplax elegans). We photographed and recorded video clips of two such episodes.
The Nakabwe mudflat (ca. $3 \mathrm{~km}$ long and $80 \mathrm{~m}$ wide) is one of the largest mudflats in the region. Local crab-hunters and fishermen of the Karen community affirmed that $C$. violacea was abundant. Surveys were conducted during neap tides (dark moon phase) at 2000-2100 h on 19 June 2017 at coordinates $12^{\circ} 53.209^{\prime} \mathrm{N}, 92^{\circ} 47.471^{\prime} \mathrm{E}$. Using headlamps and flashlights, the senior author and two trained assistants walked an approximately 50-m line transect with a distance of about $10 \mathrm{~m}$ between each observer. The mud was about $50 \mathrm{~cm}$ deep and the area was slushy. When we encountered a feeding snake, all three observers paused and recorded the coordinates of the sighting, humidity, and temperature, took photographs when possible, estimated the total body length of each individual, and resumed the survey when feeding activity ceased. To eliminate the possibility of recording the same individual more than once, counts were recorded while moving in one direction only. The snakes that were recorded did not move away, they instead remained motionless, dived into crab holes, or burrowed partially into wet mud. No snakes were collected or handled.

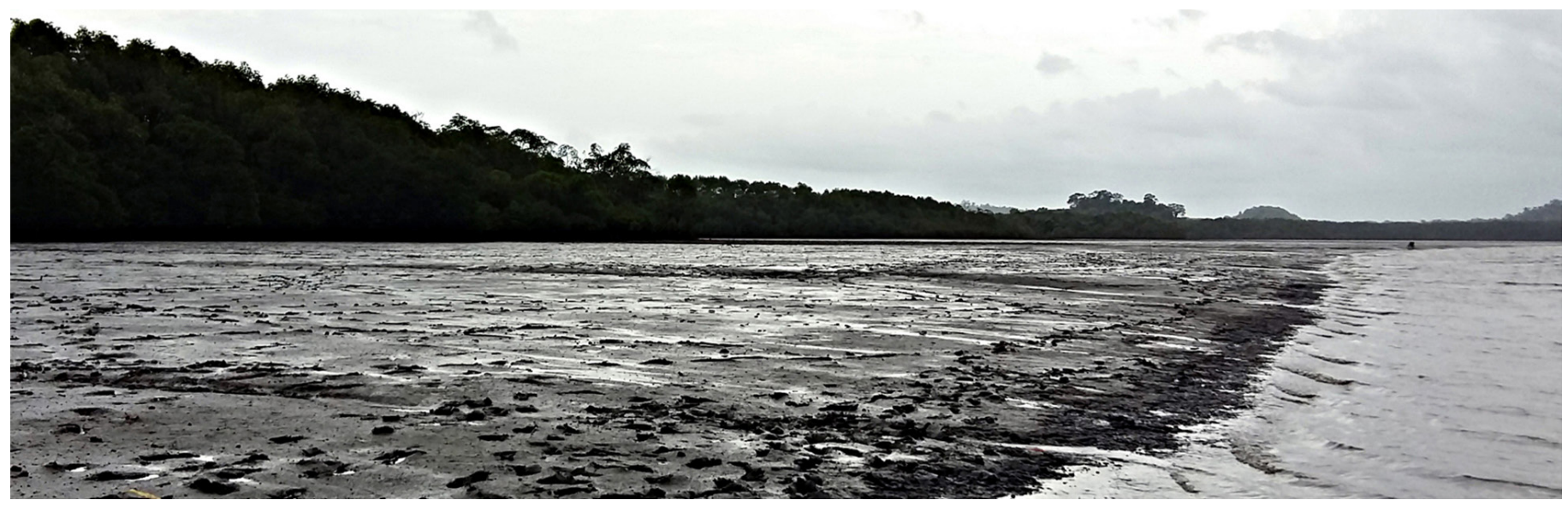

Fig. 1. The Nakabwe mudflat in the Middle Andaman Islands of India at low tide. 

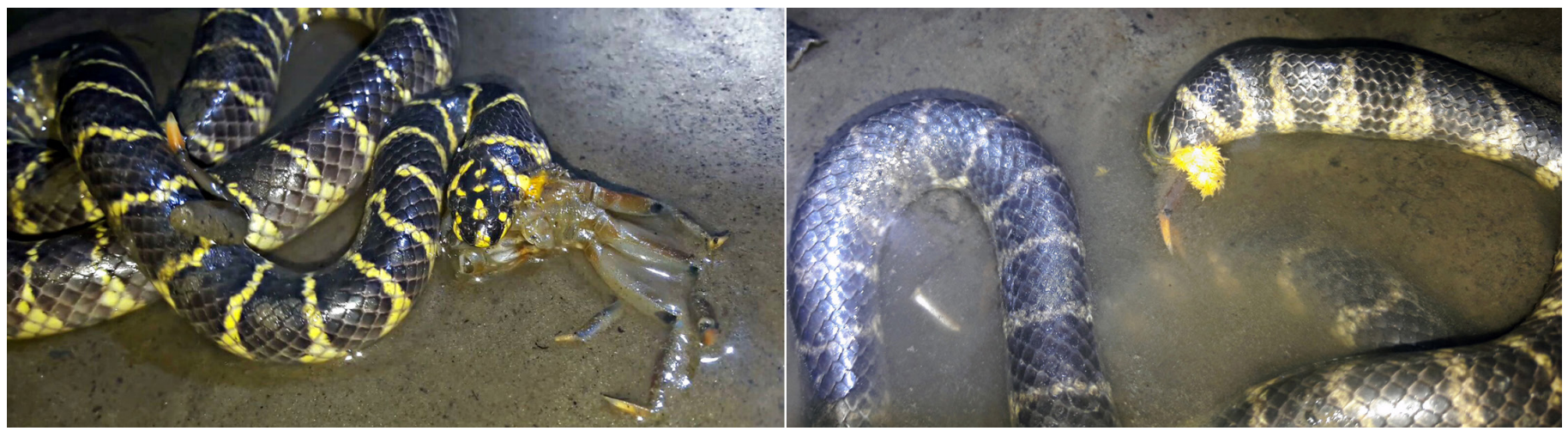

Fig. 2. Two Yellow-banded Mangrove Snakes (Cantoria violacea) preying on hard-shelled Orange Signaler Crabs (Metaplax elegans) on the Nakabwe mudflat.

We encountered 18 snakes during one hour of a single survey; two of them (ca. 80 and $100 \mathrm{~cm}$ total body length) were consuming hard-shelled Orange Signaler Crabs (Metaplax elegans; Fig. 2). We saw no snakes actually catching crabs, so we were unable to determine whether $C$. violacea is an ambush hunter, an active forager, or both. A few individuals had the tail or posterior body in a crab hole while the head and neck was swaying from side to side. Others exposed on the mudflat intermittently exhibited the same behavior, swaying the head for a brief period before moving ahead, only to stop to sway the head again. One snake used a piece of wood to anchor itself against the current in a fast-flowing brackish water stream. A number of snakes were tongue-flicking, which we interpreted as searching for prey.

Once snakes had captured a crab, they used their bodies in a press-and-pull manner to tear off the claws and most of the legs (Fig. 3) before swallowing the cephalothorax (https:// youtu.be/tu5o4eiR75s). Swallowing took about $10 \mathrm{~min}$. In one instance, a large crab approached and touched a feeding

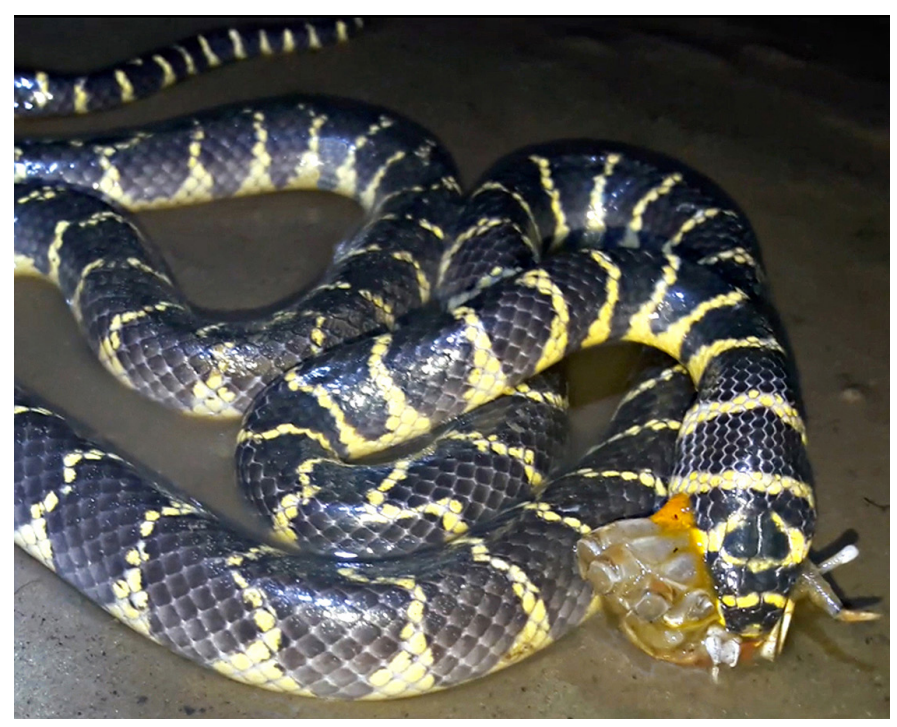

Fig. 3. A Yellow-banded Mangrove Snake (Cantoria violacea) consuming the cephalothorax of an Orange Signaler Crab (Metaplax elegans) after tearing off its legs. snake. We speculate that the second crab might have been an opportunistic scavenger.

Our observations of prey handling differ from those of Murphy (2007), who described ingestion of whole shrimp. This suggests that $C$. violacea might employ different strategies to deal with hard- and softer-bodied different prey, although we cannot rule out the possibility that dismembering hard-shelled crabs is merely an unintentional consequence of the snake maneuvering the narrow end of the crab toward its mouth.

\section{Acknowledgements}

We thank the Department of Forests and Wildlife, Andaman and Nicobar Islands, for permission to conduct fieldwork, Romulus Whitaker and John C. Murphy for pre-reviewing this note, Ashok Captain and Mandar Kulkarni for their guidance and suggestions that greatly contributed to our work, and Dr. Vinay Padate for reconfirming the identity of the crabs. We also thank the Karen people who assisted us for many years in the field; Saw John and Doris helped with logistics, and Saw Agu and Saw Thesorow assisted us in the field. The Madras Crocodile Bank Trust, Andaman \& Nicobar Environmental Team (ANET), and Dakshin Foundation provided support, logistics, and coordination.

\section{Literature Cited}

Boulenger, G.A. 1890. The Fauna of British India, Including Ceylon and Burma. Reptilia and Batrachia. Taylor and Francis, London.

Das, I. 2002. A Photographic Guide to Snakes and Other Reptiles of India. New Holland Publishers (UK) Ltd., London - Cape Town - Sydney - Auckland.

Frith, C.B. and J. Boswall. 1978. Cantor's Water Snake, Cantoria violacea Girard; a vertebrate new to the fauna of Thailand. Journal of the Natural History Society of Siam 27: 187-188.

Gyi, K.K., 1970. A revision of colubrid snakes of the subfamily Homalopsinae. University of Kansas Publications Museum of Natural History 20: 47-223.

Mattison C. 1995. The Encyclopedia of Snakes. Facts on Life, Inc., New York, New York.

Murphy, J.C. 2007. Homalopsid Snakes: Evolution in the Mud. Krieger Publishing, Malabar, Florida.

Smith, M.A., 1943, The Fauna of British India, Ceylon and Burma. Reptilia and Amphibia, Vol. 3. Serpentes. Taylor and Francis, London.

Voris, H. K. \& J.C. Murphy, 2002. The prey and predators of Homalopsine snakes. Journal of Natural History 36: 1621-1632.

Whitaker, R. and A. Captain. 2004. Snakes of India, The Field Guide. Draco Books, Chennai, India. 